\title{
Successful female expatriates as agents: Positioning oneself through gender, hierarchy, and culture
}

\author{
Maddy Janssens *, Tineke Cappellen ${ }^{1}$, Patrizia Zanoni ${ }^{2}$ \\ Katholieke Universiteit Leuven, Research Centre for Organisation Studies, Naamsestraat 69, 3000 Leuven, Belgium
}

\begin{abstract}
While most studies on female expatriates take a structural approach, this study considers female expatriates as active agents, capable of producing effective professional identities when interacting with men. We propose that female expatriates are agents who selectively interpret interactions with male actors and actively position themselves within these interactions. Within these two processes of interpreting and positioning, we examine how they draw from gender, hierarchy and culture as three power-laden identity discourses that not only constrain but also enable their actions. Through the analysis of in-depth interviews with successful female expatriates, we show how these women counter their (perceived) lower status along one identity discourse by strategically positioning themselves through a more empowering identity.
\end{abstract}

(C) 2006 Elsevier Inc. All rights reserved.

Most studies on female expatriates attempt to find explanations for why so few women hold international positions. Adler (1984a, 1984b) identified three myths in the academic literature and among practitioners: (1) women do not want to be international managers; (2) companies refuse to send women abroad; and (3) foreigners' prejudice against women renders them ineffective. When testing these three myths empirically, she (Adler, 1984b, 1994) found that only the second was grounded. Adler's work has profoundly influenced the literature on female expatriates over the last two decades, directing research towards the investigation of the structural barriers that female expatriates face (e.g., Harris, 1995; Linehan \& Walsh, 1999; Mayrhofer \& Scullion, 2002; Stroh, Varma, \& Valy-Durbin, 2000). As a result, even nowadays, when more women are

\footnotetext{
* Corresponding author. Tel.: +32 16326874 ; fax: +32 16326732 .

E-mail addresses: maddy.janssens@econ.kuleuven.be

(M. Janssens), tineke.cappellen@econ.kuleuven.be (T. Cappellen), patrizia.zanoni@econ.kuleuven.be (P. Zanoni).

${ }^{1}$ Tel.: +32 16326 893; fax: +32 16326732 .

${ }^{2}$ Tel.: +32 16326867 ; fax: +32 16326732 .
}

present and successful in international positions (Adler, 2002), little research deals with how females expatriates themselves have achieved their professional success. The few studies (Adler, 2002; Adler, Brody, \& Osland, 2000; Caligiuri \& Tung, 1999; Taylor \& Napier, 1996) in this direction still tend to stress the role of the structural context, arguing that companies should give women more chances because of their unique potential and contribution. In sum, the existing literature on female expatriates largely portrays them as powerlessly caught in a penalising structural context.

In this study, we rather consider female expatriates as agents who are able to act purposively and become successful, despite the difficulties of working in international organizational contexts. We specifically study how western female expatriates produce identities that effectively contribute to their professional success. From a theoretical perspective, we look at identities as products of interactions among individuals (Alvesson \& Billing, 1997; Gherardi, 1995). In such interactions, individuals are knowledgeable agents acting within historically specific bounds or structural constraints (Giddens, 1982; Willmott, 1987). As female expatriates 
work within predominantly male international environments, we focus in this study on their interactions with men. We explore two key processes through which female expatriates may shape their identity leading to their professional success: through selectively interpreting interactions and through actively positioning themselves within them. Our research question is correspondingly twofold: how do successful female expatriates interpret their interactions with men in predominantly male international organizational contexts? And how do they position themselves within these interactions in order to be successful?

As agents, female expatriates are always in a dialectical relationship with the discursive structure within which they are situated (Giddens, 1979). Their interactions with men as well as the identities that are produced within those interactions are constrained by the discursive structure in which they are embedded. Actors mobilize 'discursive and practical consciousness' (Giddens, 1979, p. 80, italics added), and by doing so, both make use of and reproduce structure (Willmott, 1987, p. 259). In this sense, Adler's three myths are again illuminating as they point to three structural, power-laden discourses along which identities are constructed in international settings: gender (myth one), (organizational) hierarchy (myth two), and (western) culture (myth three). Because these three identity discourses inform the interactions between female expatriates and men, they both constrain and enable female expatriates' identities. In interactions, a female expatriate can construct herself by drawing attention to or away from her being a woman, a manager, and a western expatriate. These three identity discourses are crucial in the analysis of female expatriates' agency because they represent fundamental axes of power, as reflected in the political connotation of gender, class and culture (Anthias \& Yuval-Davis, 1992).

To explore the agency of female expatriates, we rely on positive critical incidents collected through in-depth interviews with 12 successful female expatriates. While the limited, non-representative sample of respondents does not allow for generalizations, in-depth, qualitative research designs using a mixed inductive-deductive approach are suitable for explorative purposes (Eisenhardt, 1989; Glaser \& Strauss, 1967; Yin, 1989). Accordingly, our ambition in this paper is to generate a few original theoretical insights that can contribute to the advancement of our understanding of female expatriation and, in second instance, inspire new managerial approaches to it.

We start our paper with a critical review of previous research on female expatriates. Following Adler's three myths, we discuss how studies have mainly focused on structural barriers for female expatriates originating in gender, hierarchy, and culture, largely neglecting their agency. In the second section, we theorize female expatriates' agency through the notions of interpreting and positioning. Before analyzing the critical incidents, we describe our qualitative methodology and data analysis procedure. We conclude with a discussion on the contribution of this study and its implications for future research and practice.

\section{The literature on female expatriates revisited}

The low number of female expatriates in today's global business environment is a concern to most scholars writing on female executives (Adler, 1984a, 1984c; Stroh et al., 2000). Most studies focus on the difficulties women face, while a minority of them examine the sources of their success. In both cases, however, studies tend to explain the mechanisms of women's exclusion in structural terms. We discuss, in order, the structural barriers related to gender (myth one), hierarchy (myth two), and culture (myth three).

\subsection{Myth one: gender as a structural constraint}

Adler's (1984b) first myth on female expatriates expresses the idea that women have been socialized into a female gender role and that they therefore are not interested in an international assignment. This myth was exposed by the results of Adler's empirical studies (1984b, 1994), finding no differences in willingness to relocate between male and female MBA students. Nonetheless, several studies have kept locating the main barrier to women's presence in international positions in their own gender identity. They have investigated women's lack of interest in these positions (Linehan \& Walsh, 1999), their unwillingness to relocate and to move their family (Lowe, Downes, \& Kroeck, 1999), and the influence of dual careers and children on women's decision to accept international assignments (Stroh et al., 2000).

The 'gender barrier' to international assignments identified in these studies is structural in the sense that its origins are traced back to (gendered) societal values, norms and roles. The idea is that women, beyond their own control, have been socialized into specific behaviours and orientations emphasizing family life and peers rather than their jobs and careers, towards rejecting power and towards attributing their work performance to external factors rather than to internal ones, underestimating their own capabilities (Bell \& 
Nkomo, 1992; Fagenson, 1990). For instance, Fischlmayr's study (2002) argues that women exclude themselves from international assignments as they play a passive role, support traditional role models, and use vocabulary expressing little self-confidence. It is argued that precisely owing to women's own female identity, they are uninterested and unsuitable for international managerial functions and thus little present in these positions.

A few more recent studies have started to put women's female identity in a more positive light. They argue that it is precisely because of their female skills that female expatriates can become successful (Caligiuri \& Cascio, 1998; Napier \& Taylor, 2002; Taylor \& Napier, 1996). For instance, female expatriates' attention to the personal side of business and their skills in building interpersonal relationships may give them an edge over male expatriates. In spite of their more positive approach, valuing those same female skills that the literature has traditionally devalued, these studies still portray female skills as structural in the sense that women simply 'have' them by virtue of being women. Women are thus no agents, as their purposive deployment of their skills to reach favourable professional aims remains unacknowledged.

\subsection{Myth two: hierarchy as a structural constraint}

The second myth on female expatriates indicates that western (particularly, North American) managers are reluctant to send women abroad (Adler, 1984b). Adler's (1984a, 1994) empirical findings supported this myth as managers consider an international assignment by a woman to be a high risk-operation. They locate the problem either in the women themselves or in the surrounding context. In any case, managers use arguments such as physical safety, hazards involved in travelling in developing countries, isolation and loneliness, possible negative reactions of superiors, subordinates, clients and colleagues towards women in managerial positions as reasons for likely failure rates among female expatriates (Adler, 1994).

Similarly to myth one, myth two reflects a structural barrier beyond female expatriates' control. The reason for the scarce presence of women among expatriates is to be located in their comparatively low position in companies' hierarchy, which means that they are likely to have male superiors who judge them unsuited for international assignments. Many recent studies on female expatriates seem to investigate this exclusion mechanism. They have identified a large range of difficulties throughout the international transfer pro- cess, both overt and covert (Linehan \& Walsh, 1999), including traditional HR-instruments like selection procedures, training, and preparation (Mayrhofer \& Scullion, 2002), senior managers' prejudices (Adler, 1994; Harris, 1995; Stroh et al., 2000), as well as the exclusion of women from formal and informal networks fundamental for upwards mobility (Izraeli \& Adler, 1994; Linehan \& Walsh, 1999; Mayrhofer \& Scullion, 2002). The fact that expatriate positions tend to be relatively high in authority and status (Edström \& Galbraith, 1977) might further hamper women from getting them, as they need to overcome both the barriers to climbing the organizational ladder and the ones specific to international assignments. By focusing on the possible barriers within the organization itself and relating them to the women's subordinate position to male managers, the studies falling under myth two clearly focus on structure at the expense of agency. As for myth one, women are largely portrayed as caught within a system on which they have little control.

\subsection{Myth three: culture as a structural constraint}

Adler's (1984b) third myth asserts that women will not be effective in other cultural environments because foreign managers have culture-bound prejudices against female managers. The argument is that female expatriates cannot be successful internationally because, in other cultures, women do not have equal status with men. The women-unfriendly environment in the host country will thus render female expatriates ineffective. Although this argument is often used by managers as the main reason for not sending a woman on an international assignment, Adler's $(1987,1994)$ empirical results indicated that this myth is not founded. Similar to other research (Westwood \& Leung, 1994), she rather holds that the 'Gaijin syndrome' prevails, for which 'all foreigners are foreigners regardless of their sex,' meaning that female expatriates are not associated with local women but rather with male expatriates.

As for the previous two myths, this literature looks for structural barriers to women in international management. In this case, the reason for not giving international assignments to women is linked to the culture of the host country. Some studies (Adler, 2002; Napier \& Taylor, 2002; Taylor \& Napier, 1996) however, reinterpret this structural barrier as an advantage for women working internationally. For instance, female professionals in Japan mentioned that their higher visibility and memorability were positive for their adjustment and work success (Taylor \& Napier, 1996). As in the case of myth one, although the effects 
of culture are considered positive rather than negative, the perspective mainly remains centred on culture as a structural factor and women's agency is underplayed. Only one study (Napier \& Taylor, 2002) suggests the active use of 'femininity' by female expatriates to deal with 'older Chinese men' as a way to gain information.

Overall, this critical review of previous female expatriate studies suggests the following research proposition:

Proposition 1. Structural barriers encountered by female expatriates are related to three key power-laden discourses structuring the international contexts in which they operate: gender, hierarchy and culture.

\section{Theorizing agency: interpreting and positioning}

To study female expatriates' production of identities conducive to their professional success, we assume that a person's identity is discursively produced and reproduced in the micro-contexts of interpersonal interactions (Acker, 1990; Alvesson \& Billing, 1997; Gherardi, 1995; Goffman, 1959; West \& Zimmerman, 1991) and that, within these interactions, a person is an agent. Following a number of sociological and feminist work (Giddens, 1979, 1982, 1984; McNay, 2000; O'Donnell, 2003; Skeggs, 1997), we understand agency as the capacity of individuals to act purposively in the social world. Human beings are in this sense 'not just ciphers from which subject positions can be read off; rather they are active in producing the meaning of the position they (refuse to, reluctantly or willingly) inhabit' (Skeggs, 1997, p. 2). At the same time, however, agents are not completely free, as agents always act within historically specific (discursive) bounds (Giddens, 1979, 1982). In order to understand the dialectical relation between agency and structure, we need to acknowledge that structural barriersreflecting existing power relations-do not only constrain but also enable actions (McCabe, 2000). Particularly, the three identity discourses of gender, hierarchy and culture, along which power relations are structured, foreclose and open up possibilities for female expatriates to produce identities leading to their professional success.

Proposition 2. Female expatriates are situated within a particular power-laden discursive structure that not only constrains but also enables them as agents.

We specifically explore two processes through which female expatriates act as agents. One process deals with the way they interpret their interactions with male actors in international organizational contexts. A second process concerns the way they position themselves within those interactions.

\subsection{Interpreting interactions with male actors}

In order to act purposively upon the social world, human agents first need to make meaning of it. Because female expatriates are in a male dominated world, they particularly need to make sense of their interactions with men and interpret them. As social interactions are inherently ambiguous, individuals make sense of them through processes of negotiation, conflict, and improvisation (Gergen \& Davis, 1985; Van Maanen, 1979) during which they draw from their beliefs, values and available discourses. The different modes of constructing social reality are not true or false but rather important because they entail a logic for action.

Further building on this theoretical perspective, we propose that successful female expatriates' interpretations of their interactions with male actors are important because they constrain as well as enable their attempts to build an identity that is conducive to their success. In particular, we explore the ways in which female expatriates draw from the identity discourses of gender, hierarchy, and culture in order to solve the ambiguity inherent to social interactions within the context of international assignments. Again, these identity discourses are important because they are power-laden, and power both enables success and is reproduced by it.

Proposition 3. Female expatriates interpret interactions with men in international contexts by drawing from the identity discourses of gender, hierarchy and culture.

\subsection{Positioning oneself within interactions with male actors}

Interpreting interactions in certain ways constrains and enables the way in which human agents can subsequently act or position themselves within interactions. Davies and Harré (1990) see 'positioning' as a linguistic practice producing the self in encounters. Positioning has been used by Gherardi and Poggio (2001) to investigate how women 'do gender,' by taking specific positions (cf. Gherardi's (1995) archetypes) within the social practices that define them as women in their relationship with men. In this study, we extend the notion of positioning to include 
hierarchy and culture as two additional key identity discourses available to female expatriates to act within interactions in order to be successful.

As in the process of interpreting, we expect that female expatriates can position themselves in interactions with men by drawing on the identity discourses of gender, hierarchy and culture. The few studies that go in the direction of female expatriates' agency provide preliminary evidence for this assertion. Female expatriates may use what they consider women's unique qualities such as interpersonal skills (Adler, 2002) or their 'femininity' (Napier \& Taylor, 2002), to position themselves. Gherardi and Poggio's (2001) study identifies an additional positioning strategy, taking a 'one down position' to avoid direct competition with male colleagues, showing humility towards the male hierarchy to safeguard a broader playfield within the organization. We would argue that, in these cases, the positioning process draws on the identity discourse of gender. Alternatively, female expatriates can position themselves by referring to the differences between their own (western) culture and the culture(s) of the men they interact with. A cultural positioning process is the use of the 'Gaijin syndrome' (Adler, 1994), when a female expatriate accentuates her 'foreignness' to take advantage of her culture's higher status. Finally, a positioning strategy can also draw on the identity discourse of hierarchy. Although we found no indications for this in previous studies, we propose that female expatriates can contribute to their success through accentuating their superior rank vis-à-vis men in lower positions.

Proposition 4. Female expatriates position themselves along the identity discourses of gender, hierarchy and culture in ways that are conducive to their professional success.

\section{Methodology}

To explore the agency of female expatriates, we conducted in-depth interviews with 12 successful female expatriates. Since there are a rather limited number of women holding international positions, we used snow-ball sampling. This technique is based on chain referral (Biernacki \& Waldorf, 1981; Goodman, 1961), a procedure recommended for sampling rare populations (Kalton \& Anderson, 1986). In our case, we first contacted a few international companies in Belgium asking to bring us in contact with 'successful' female expatriates. Following other studies on expatriation, we defined success along three concrete criteria: (1) a successful female expatriate has completed an international assignment, (Black \& Gregersen, 1991; Caligiuri, 1997; Tung, 1981); (2) she has been sent on different international assignments by the same parent company because of her job performance (Caligiuri, 1997) and trust in her (Janssens, 1994); and (3) she shows continued willingness to work internationally as a sign of being psychologically comfortable with living and working in another country (Black, 1990; Caligiuri, 1997; Church, 1982). Through relying on these three criteria, we can assume that not only the female expatriates judged themselves as successful but were also considered by others as such. We do, however, assume that their own perception of how they successfully manage international assignments can provide us with relevant insights on successful strategies. This assumption fits our theoretical perspective as we consider female expatriates to be agents, able to act effectively in difficult situations. The fact that these women are also judged by others as successful indicates their ability to do so. Once we had established the first contacts with a few female expatriates, they re-directed us to other colleagues and/or friends having the same profile.

The interviewees are all Caucasian western expatriates coming from Austria, Belgium, Canada, The Netherlands, the UK and Sweden. They fulfilled expatriate positions in many different countries and regions such as Ireland, France, Switzerland, Singapore, China, USA and the Middle East. At the time of the study, they all held a managerial international position mainly in the domains of marketing, sales and HRM. The international companies in which they worked operated in the chemical, electronic, construction, energy and steel industries.

Interviews were conducted in 2001 and 2002. They took place either at the interviewees' homes or at their work, as preferred by individual interviewees. The location did not affect interviews' length which was between 1.5 and 2 hours. We used a semi-structured format asking the female expatriates about (1) their predeparture experiences and (2) their experiences in completing the international assignments. For both types of experiences, questions referred to their own motivation and skills, the role of the company and local managers, and their personal family situation. At the end of the interviews, we asked the female expatriates to report on 'critical incidents' (Flanagan, 1954), both positive and negative, which they considered to be relevant in the pursuit of their expatriate career. The critical incident technique is used for 'systematically identifying behaviors that contribute to the success or failure of individuals or organizations in specific 
situations' (American Institute for Research, 1998). All interviews were tape-recorded and fully transcribed.

To analyse our data, we first listed all reported critical incidents, both positive and negative. Since our aim is to explore the ways in which successful female expatriates act as agents, however, we selected only the positive ones for analysis. Out of this group, we retained the 17 critical incidents in which the interviewees described an interaction with male actors and which indicated concrete behaviors, feelings or thoughts. In line with triangulation principles (Denzin, 1978), each incident was then classified separately by each author in terms of the different ways in which the female expatriates interpret the interactions and position them. Whenever disagreements arose in our classification, we went back to the full original interview text and discussed the incident till consensus was reached.

In classifying incidents, we identified the interpretation of an interaction as (i) gendered when the female expatriate understands it as the result of given gender roles and relations, (ii) hierarchical when she understands it as the result of given hierarchical relations between superiors and inferiors in the organizational context, and (iii) cultural when she understands it as the result of cultural differences. We identified interviewees' positioning within an interaction along the three same identity discourses: (i) gendered when the female expatriate relies on so-called female skills, (ii) hierarchical when she uses the power deriving from her position in the organizational hierarchy or relies on superiors having more power than herself, and (iii) cultural when she relies on her (inter)cultural competences.

Finally, we analyzed seven critical incidents in depth. We selected rich incidents that help us to theorize on female expatriates' agency in producing an effective professional identity. In the next section, we provide an overview of the 17 critical incidents and present the analysis of the seven selected extracts.

\section{Successfully doing woman-manager-western expatriate}

Table 1 presents all 17 retained positive critical incidents and our analysis in terms of interpreting and positioning. When analyzing the ways in which female expatriates interpret their interactions with men, three of the interactions were classified as gendered, two as hierarchical, and six as cultural. Next to these 11 incidents, we analyzed the 6 other incidents as a combination of two identity discourses. In these cases, female expatriates interpreted their interactions by simultaneously drawing on two discourses. Four interactions were classified as a combination of culture and gender, and two as a combination of gender and hierarchy.

When analyzing interviewees' positioning strategies, the same identity discourses of gender, hierarchy and culture were found to be relevant. Female expatriates tended to position themselves along gender, hierarchy or culture to strengthen their position vis-à-vis men. Further, our analysis indicates that our interviewees appeared to systematically position themselves along another identity discourse than the one they used for interpreting the interaction. Specifically, when interpreting the interaction as gendered, our respondents used hierarchical or cultural positioning; when interpreting the interaction as hierarchical, they relied on gendered or cultural positioning; and when interpreting the interaction as cultural, they used gendered or hierarchical positioning. The same rationale occurred for the combined cultural/gendered interactions as female expatriates used hierarchical positioning. Only in the gendered/hierarchical interactions, our respondents didn't rely on cultural positioning as we expected but relied on another, not anticipated discourse, e.g., expertise or their professional capabilities.

In the following paragraphs, we discuss these findings in-depth through selecting seven incidents: two gendered, two hierarchical, two cultural interactions, and one cultural/gendered interaction. These incidents were selected as they helped us in our attempt to theorize on female expatriates as active agents. We systematically analyze how female expatriates interpret an interaction with men by referring to a particular identity discourse and how they consequently position themselves by relying on another discourse in such a way that is conducive to their success. For the mixed gendered/hierarchical interaction, we reflect in the discussion on why female expatriates resort to an alternative discourse such as expertise to strengthen their position.

\subsection{Positioning oneself within gendered interactions}

The two selected critical incidents interpreted as gendered interactions come from one and the same interview with Susan, one of the most experienced female expatriates in our sample. Susan is from the UK and, at the time of the study, worked in Belgium as an international sales manager in the construction sector. She has more than 20 years of expatriate experience and has carried out assignments in Norway, Singapore, the 
Table 1

Female expatriates' interpreting and positioning within critical incidents

\begin{tabular}{ll}
\hline $\begin{array}{l}\text { Critical } \\
\text { incidents }\end{array}$ & Interpreting \\
\hline 1. & $\begin{array}{c}\text { Gendered interactions } \\
\text { A man asks her in a denigrating way to serve } \\
\text { coffee in a meeting } \\
2 .\end{array}$ \\
Male colleagues doubt her capacity in this \\
job because of her gender
\end{tabular}

3. Men make remarks about her being a woman

4.

15. Korean employees have informal post-negotiation

16. parties excluding women

\section{Gendered/hierarchical interaction}

She receives less salary compared to male colleagues

\section{Hierarchical interactions}

Her boss has difficult relationships with his subordinates because he fears competitive behavior

She has a high hierarchical position in the corporation which influences her relationship with local employees

\section{Cultural interactions}

Working with Chinese employees is difficult because they tend to shut you out if you misbehave and never say 'no'

She experiences the Korean employees as very hesitating, doubting and not responding

She experiences the Italian service centre as not listening to other European customers, being very arrogant, thinking they know what is best all the time

As an English expatriate, she does not spend a lot of time talking and discussing, which conflicts with the style of the Belgian management team

She experiences Singaporean production workers to deceive their superiors and to be unreliable

She tends to use her western direct negotiation style but her Korean business partners are completely unresponsive

\section{Cultural/gendered interaction}

Korean employees object towards her, a woman, doing the negotiations

A Scottish subordinate is unwilling to talk to her about job related problems because of his Scottish belief (no women in higher hierarchical positions)

She experiences Japanese men to have difficulties with women in business due to headquarters' categorization and compensation system

Top management (male) from headquarters visits the Singaporean plant and ignores her

\author{
Positioning
}

\section{Hierarchical positioning}

She pours coffee in his lap and throws him out of the meeting because she has the authority to do so

She talks to her boss and makes him stop the rumours

\section{Cultural positioning}

She mentions her cultural background-Scottish roots-as she experiences this as a stop in the conversation

\section{Gendered positioning}

She makes him feel comfortable so that he is less threatened by her than by her male colleagues

\section{Cultural positioning}

She always respects the local cultural habits and values

\section{Gendered positioning}

She uses her female skills to adapt herself and pay attention to small things

She wraps them around her finger, the company calls her its 'secret weapon' in Korea for her femininity

When going against their logic, she is honest and maintains a good personal relationship, an ability that she thinks women have more than men

She has a very open and vulnerable conversation about it, which is easier for women as they are more 'in touch' with their feelings

\section{Hierarchical positioning}

As their supervisor, she follows up production very strictly, constantly controls them and is a 'bitch' just to make sure the work gets done

She asks her boss to conduct some informal negotiations

\section{Hierarchical positioning}

She tells them 'to take it or leave it' as she received authority from headquarters to conduct the negotiations

During the yearly performance evaluation, she gives him a low score on behavior

Even though she is in a high hierarchical position, she puts herself in a subordinate position and lets her male supervisor do the talking

She enforces her involvement through emphasizing her leadership within the negotiating team

\section{Positioning through expertise}

She demonstrates her functional capabilities and experience in order to stress her equal value

She demonstrates her skills in a presentation in order to make them listen to her 
Philippines, India, China, the Middle East, USA, and The Netherlands. The following excerpt reports one of the critical incidents she told us:

'We had a team meeting and I arrived a bit late. Before the meeting, there is always some small talk, so they had not started yet, everybody was still talking, but they were all seated. There was somebody new at the meeting who was not aware of whom I was. He was a guest who had been invited for a specific reason. This man came to me and said: 'Hi honey, I like my coffee with milk, will you get me one?' Suddenly, everybody in the room fell silent. I said: 'Of course, take a seat. I'll get it for you.' When I came back, I poured the coffee in his lap. I said that if he ever said something like that to me again or to another woman while I could hear it, he would get more than coffee in his lap. I was especially angry because of the way he had said it, in such a patronizing way. It was no joke, he really meant it. He got angry and started screaming at me. I did it again and then threw him out of the meeting. I had the authority to do so. I did not file a formal complaint, but I made sure everyone in the firm knew. I made sure they gossiped about it, which is much more destructive than a formal complaint.'

By addressing Susan as 'honey' and asking her to bring him coffee, the male character in this text draws from traditional gender roles to define Susan as a woman and to make her subordinate to him, a man. Because she is a woman, Susan is assumed to fulfil a low-status support job. As a woman in a lower job, the male guest finds it appropriate to use the sexually denigrating appellation 'honey' and to ask her to get coffee for him. Accordingly, Susan interprets this interaction as gendered. To position herself within this interaction, she first boldly pours coffee in his lap and then throws him out of the meeting. Because she outranks him, she can use her authority to turn this interaction into a successful one for herself. While pouring coffee in somebody's lap may be a strange reaction, her superior hierarchical status enables her to make this bold statement and then throw the man out. Further, she consciously chooses not to play it by the rules as filing a formal complaint would stress her weak position as a woman. Rather, she decides to rely on the informal grapevine to portray herself as the more powerful and thus successful actor in the interaction.

In another part of the interview, Susan talks about her experiences as a female expatriate manager in the Middle East. Here again, she interprets these interactions as gendered, rather than as cultural, as indicated by her comparison with her experiences in European countries:

'In the Middle East, they would never treat me as a local woman; they wouldn't dare because they know I'm not. But sometimes they make a slight remark about me being a woman, but that's just their culture, they can't help it. This is not only true for the Middle East, but also for The Netherlands, Belgium, Germany and France. If so, I mention my Scottish roots. That always makes the conversation stop. I see people making associations with Scotland and wondering what kind of person I am and how they should interact with me. I am immediately categorized as 'different', they don't know how to react and they don't know how to manage me, because a Scottish person reacts differently.'

In this fragment, Susan points to the fact that her gender remains a striking factor throughout her various international assignments. Later on in the interview, she attributes this to the mentality within the construction industry, which is still very traditionally male oriented. To position herself throughout these gendered interactions, Susan often actively makes use of her cultural background. In conversations when the 'woman issue' comes up, she disorients the men she interacts with by mentioning that she is Scottish. The reference to her specific cultural background, a Scottish one, rather than British, renders her mysterious and different from other women, which draws attention away from her gender difference from her male colleagues. Through accentuating her culture, Susan creates ambiguity and consequently improves her position within a male dominated context. While as a woman, she can be put in a low power position, as a Scot, it is more difficult to do so either because people know little about Scottish culture or because, if they do, they are aware of the rebelliousness Scottish people are known for. Susan makes her identity 'unmanageable,' and therefore more powerful.

These two excerpts indicate how a female expatriate interprets difficult interactions with men as structured by the identity discourse of gender. Susan interprets her less powerful position as the result of her being a woman. To position herself as more powerful, she strategically draws on other available identity discourses that enable her as an agent to be successful: hierarchy in the first interaction and culture in the second. While Susan cannot completely hide the fact that she is a woman, she can neutralize the disadvantageous lower status that is associated with being a woman by foregrounding her other identities to construct a powerful and successful professional identity. 


\subsection{Positioning oneself within hierarchical interactions}

We present two incidents which our interviewees interpreted as being structured by hierarchical relations, each however, using a different positioning process. In the first, the interviewee positions herself through gender, in the second through culture.

Sabien is a rather young Belgian lawyer who, at the time of the study, was carrying out an assignment in Singapore for a large Belgian governmental energy concern. As this company had been expanding its activities internationally to prepare for the liberalization of the Belgian energy market, she had completed international assignments in the USA, New Zealand, China and South Korea. In the following excerpt, she tells about her experience in South Korea:

'My boss back there had a rather difficult personality and that didn't work well with other men. Men tend to show a lot of competition, want to show who's the best and want to take on a leadership position. I handled it in quite a different way. As a woman, you have other qualities, and I made my boss feel more comfortable around me, he felt less threatened. I dealt with him in a softer manner; and that's why we got along. He felt comfortable around me and considered me less of a threat than my male colleagues. At first, it was because he thought: 'Oh, a girl, I will be able to dominate her much easier and handle her much better.' But because I used another approach, I could gain much more from him. In fact, his father instincts came out and I took advantage of that professionally.'

In this fragment, Sabien reflects on her relationship with her boss in South Korea, rather than recounting one specific interaction with him. Nonetheless, she refers specifically to how men interact among each other, and how she chose to interact with her boss in another way. She first interprets the interactions as hierarchical, as she is clearly in a subordinate position to her boss, and by mentioning that also male colleagues had difficulties with him as well as by making no reference to his cultural background. To position herself within this hierarchical interaction, Sabien actively draws from her gender identity. She accentuates her femininity by using 'female skills' to make her boss feel comfortable around her and avoid being perceived as a competitor. Using the positioning tactic that Gherardi and Poggio (2001) call the 'one-down position,' Sabien is able to safeguard her position and even broaden her playfield by playing the feminine identity card. This positioning process reassures her boss of his higher position but at the same time enables her to obtain more from him. Through drawing from this identity discourse of gender, she is able to turn a potentially unfavourable relationship, in which she is the less powerful party, into one that is beneficial to her career.

Tine is another Belgian expatriate who at the time of the study just returned from an international assignment in Singapore. As a middle manager, she worked there for a venture fund of a big holding investing in technology and telecommunications. She completed international assignments in The Netherlands, the USA, the Philippines, Ireland, and France. In the following fragment, she tells about her experience in Singapore:

'The other women in the company mainly held administrative positions. I had a rather high position in the hierarchy and I was the only expat. From that perspective, I was unique, but I never experienced it in that way. I could get along very well with my colleagues, and the supervisors who reported to me really treated me with respect. Of course, there is a big difference between us, and there was little contact with them after work. But I always respected their norms and values. There was never any envy, except for the director. ... However, in the factory I was regarded as a curiosity. The fact that I was a foreigner and white was very extraordinary. I don't think many white women had been there, so I guess the fact that I was foreign and especially white, made me so special, much more than the fact that I was a woman.'

As in the previous fragment, the respondent reflects on her experience as expatriate rather than reporting specific interactions. Tine mainly stresses the importance of her position in the hierarchy to define the quality of her relationship with the local employees who worked for her. Although she does introduce gender and culture as additional factors, her rank seems to be most important in affecting her interaction with local employees. Positioning herself, Tine draws attention to her own consciously respectful approach to the local culture leading to mutual respect between her and her employees. While she experiences herself as a superior only along one identity dimension, hierarchy, she reduces the cultural (power) distance, which results in better relationships with the local employees, if not with the local director.

These two incidents indicate how, next to gender, hierarchy is another power-laden discourse structuring the international context in which female expatriates operate. These two Belgian expatriates interpret their 
difficult position as the result of hierarchical relations. To position themselves within these hierarchical interactions, they however act as agents by making active use of respectively gender and culture as enabling identity discourses in their pursuit of success. While Sabien, who is in a subordinate position to her boss, uses her female skills to build a non-threatening relationship with him, Tine builds positive professional relationships with her local personnel by drawing her power from her superior hierarchical status and having a respectful attitude towards the local culture. Although the two female expatriates draw from different identity discourses, both their positioning strategies 'soften' the power relation between themselves and those actors on which their work depends, facilitating their professional success.

\subsection{Positioning oneself within cultural interactions}

Here, we analyze in-depth two incidents in which cultural differences are seen as determining female expatriates' interactions with male actors. As in the two previous paragraphs, we discuss how female expatriates position themselves by means of the remaining identity discourse of respectively gender and hierarchy.

Heidi is Austrian and worked, at the time of the study, in Belgium as product manager for a multinational company in electronics. She has worked for this company for several years with previous international assignments in The Netherlands and China. In the following fragment, she reflects on her experience in China:

'I always made sure I adapted to the foreign culture in which I worked. I think this is one of the female advantages, to be able to adapt so quickly. Often, very small things turn out to be very important. For example, the Chinese tend to shut you out if you have misbehaved in any way. Also, they never say no, everything is always very good. If you ask them if the project is doing well, they will always confirm. Problems tend to remain hidden, so you have to communicate in a very different manner if you really want to find out. You need to build mutual trust to get to such information, or they will shut you out. The contact with a foreign culture is often limited, but I use it as efficiently as possible. I inform myself over the host culture, read about it and prepare myself.'

This fragment is a reflection on interactions with Chinese colleagues. She experiences difficulties in working with them and interprets these difficulties in terms of their culture: the Chinese shut you out if you misbehave and they tend to hide mistakes. The fact that she is a foreigner puts her in a disadvantaged position as she needs to learn the local cultural code in order to be effective in her work in the Chinese context. To position herself within these cultural interactions, Heidi not only actively informs herself about the culture but, above all, actively uses her 'feminine' skills: her ability to quickly adapt and her attention for small things. These skills allow her to build the necessary mutual trust relationships in spite of her limited contact, as an expatriate, with the local culture. In this incident, hierarchy does not seem to play a big role. Rather, Heidi refers to her gender identity, her female skills, in order to fit into a different cultural context and to be successful.

The second incident of a cultural interaction is taken from the interview with Tine, whom we have introduced above. In this fragment, she recounts her experiences as a supervisor of Singaporean employees:

'Having Singaporean employees as production workers was not an easy job. The Indians [in her previous job] respected quality and hygiene standards. The Singaporean employees however always deceived you, even in your presence. They also smoked in the factory. I worked day and night, I controlled production constantly. I was very authoritarian, very strict and always controlling. I was a 'bitch' just to make sure the work was done in the proper way.'

Tine interprets the behaviour of Singaporean workers toward their job as a cultural phenomenon. She portrays it as particularly problematic by comparing it to the Indian culture. Singaporeans deceive supervisors, elude quality and hygiene standards, and smoke in the factory. In order to counter such negative behaviour, and ensure production, Tine deploys her authority as a supervisor, constantly controlling workers and being very strict with them. She relies on the power of her hierarchical position to enforce the desired behaviours.

These two critical incidents indicate how culture is a third power-laden discourse that can structure female expatriates' interactions with men. These interviewees interpret their difficulties as originating in local cultures. Similar to the incidents above, they however, actively position themselves by relying on other, enabling identity discourses. Heidi could learn to deal with the indirect Chinese communication style because she, as a woman, pays attention to small things and adapts, which enabled her to build the necessary trust relationships. Tine effectively deployed her hierarchical position to overcome culturally determined 
behavior of Singaporean employees ignoring quality and hygiene standards.

\subsection{Positioning oneself within cultural/gendered interactions}

Besides interpreting interactions with male actors along one identity discourse, our analysis indicates that female expatriates also interpret interactions simultaneously along two identity discourses. As Table 1 indicates, four critical incidents were considered to be interpreted as both cultural and gendered. In these instances, our interviewees encountered difficulties with men due to the men's cultural beliefs about the position of women in business. To position themselves within such interactions, the female expatriates draw from the identity discourse of hierarchy, the only other remaining available discourse. As in the previous cases, this positioning process refers to either one's own positional power or to the positional power of one's supervisor.

To further discuss how this interpreting and positioning process takes place, we present a critical incident from the interview with Sabien, whom we have introduced above. In this fragment, Sabien draws on her own hierarchy to counter her disadvantageous position as a woman in the South Korean business culture:

'They sent me on the assignment and I experienced an attitude of wait and see towards me. South Korea is a typically male society, women are absolutely not allowed to work there. In the beginning, I felt resistance, Korean men objected towards me doing the negotiations, but I told them I would do the job I was supposed to do and they had to take it or leave it. Afterwards, I gained respect from these Korean men during negotiations and it [being a woman] even turned out to be an advantage. For them, it was something special, a woman doing negotiations in a male society and even a blond woman! It was somehow exclusive. I never had any problems with it. On the contrary, it turned out to be an advantage. Sometimes they even called me Hillary Clinton. As a local woman, this would never have been appropriate, but I held a different position.'

Sabien interprets her difficulties in terms of both cultural and gender differences as the objections to her conducting the negotiations occur because women are not expected to work in the South Korean culture. To position herself within these interactions, she actively makes use of her hierarchical position. Sabien stresses the fact that negotiating is part of her assignment and accentuates her hierarchical power when she tells the South Korean counterpart to take it or leave it. Her successful performance in the job subsequently led to respect and even turned out to be an advantage, as she then came to be perceived as unique, an exclusive western female manager, as the comparison with Hillary Clinton, a powerful western (blond) woman indicates. In this case, Sabien was able to turn her low power position along the culture and gender dimension into a success through her high power position along the hierarchy dimension. Through the virtue of her hierarchical position, she could frontally challenge her counterparts' cultural assumptions about women and clearly distinguish herself from South Korean women.

\section{Discussion}

In contrast to previous literature on women in international management, this study proposed a new theoretical approach that considers female expatriates as agents rather than exclusively as victims of a penalising structural context. Through an explorative study with successful female expatriates, we showed how they, as agents, actively produce effective professional identities and make their own success as 'woman,' 'manager,' or 'western expatriate.' To reflect on this theoretical contribution, we discuss the degree to which our findings confirm the previously formulated propositions.

Consistent with Proposition 1, the female expatriates in our study encountered structural barriers that are related to the discourses of gender, hierarchy and culture. The critical incidents they reported, all referred to these three power-laden discourses that we derived from Adler's (1984b, 1994) three myths. Operating in international contexts, female expatriates can experience difficulties in interacting with men due to gender, hierarchy or culture.

Our data also tend to confirm Proposition 2 which stated that these same identity discourses of gender, hierarchy and culture do not only constrain female expatriates in international contexts but also enable them to produce particular identities leading to their professional success (Giddens, 1979). Throughout the critical incidents, female expatriates reported how they turned to these three discourses as a resource to build effective professional identities. From a theoretical perspective, precisely because power relations are structured along multiple identity axes (McCabe, 2000), female expatriates can, as agents, spot and actively make use of possibilities to be effective by selectively using gender, hierarchy or culture. 
Considering female expatriates as agents, we further proposed two types of processes through which female expatriates produce their own successful identity: interpreting (Gergen \& Davis, 1985) and positioning (Davies \& Harré, 1990; Gherardi \& Poggio, 2001). Our data also tends to confirm this analytical distinction. First, female expatriates interpreted interactions with male actors in terms of one-or sometimes twoidentity discourses (Proposition 3). This sense-making process is crucial, as it constrains and enables subsequent possible course of action. The key to female expatriates' success seems to be rooted in their 'appropriate' understanding of the situation, that is, an understanding which makes clear that they are in a subordinate position but, by so doing, also delimits that subordination to a specific type of identity discourse. Second, female expatriates positioned themselves within difficult situations in a favourable way by drawing from one of the identity discourses (Proposition 4). After interpreting the situation according to a particular identity discourse, they actively make use of an enabling identity discourse to produce a particular successful identity. Female expatriates can become a successful woman, a successful manager or a successful western expatriate, depending on their positioning strategy.

Besides confirming the four propositions, the analysis of our data suggests two additional theoretical findings. First, the female expatriates in our study did not position themselves just along any of the three identity discourses; they positioned themselves along that identity discourse in which they felt more powerful. Precisely because successful female expatriates seem to be able to interpret difficult situations according to a particular identity discourse, their interpretation process opens up possibilities to use other available and relevant identity discourses to position themselves in a more favourable way. They can, in other words, try to counter their lower status along one (or two) identity discourses by strategically drawing from a more empowering identity to define themselves in interactions.

A second additional finding refers to the existence of other available identity discourses along which female expatriates can position themselves. Next to the three power-laden discourses of Adler's myths (1984b, 1994), our analysis suggests the relevance of expertise as an additional power-laden discourse. Two female expatriates turned to their functional expertise and capabilities when they interpreted the interactions as a combination of gender and hierarchy (see Table 1, critical incident 16 and 17). In both incidents, the female expatriates could not position themselves along culture, the remaining identity discourse, as both situations referred to interactions with men in headquarters, having the same cultural backgrounds. Because culture was not an available positioning option, these interviewees turned to a more 'individual' source of power and legitimacy, their expertise and experience. Relying on the identity discourse of a professional expert, they could still turn a difficult situation into a successful one. This analysis suggests that, while the three power-laden discourses of gender, hierarchy and culture may be prominent in international contexts, successful female expatriates may turn to alternative identity discourses to counter a low status position in case no prominent discourse is available.

\section{Implications for research}

This explorative study has clearly indicated that female expatriates are agents and have an active role in their success through the way they interpret and position themselves within interactions with male actors. This research perspective moves away from merely descriptive analyses of the problems female expatriates encounter towards a more theoretically grounded, critical approach to women in international management. This field of literature can benefit from an agentic approach providing insights in the micro-dynamics of power characterizing international assignments.

Taking such a perspective, future research may address the following issues in order to overcome some limitations of this explorative study. First, it may employ a more exhaustive methodological approach than the explorative one used here. A larger and more theoretically driven sampling of respondents is needed to further test and refine our theoretical insights about female expatriates' agency.

Second, we were mainly interested in the identity discourses of gender, hierarchy and culture as suggested by Adler's three myths and interviewed only Caucasian western female expatriates regarding their agency and these three identity discourses. Future research may want to consider other power-laden discourses that structure international contexts and provide female expatriates with interpreting and positioning options. While this study already indicated the relevance of the identity discourse of expertise, studying non-western female expatriates may have the potential to identify other identity discourses such as class and age.

Third, we focused in this study on female expatriates' interaction with male actors. Although this focus is legitimate given the male dominance of the international management context, future research may want to study female expatriates' interaction with other 
female actors. Because some studies (Napier \& Taylor, 2002) suggest that female expatriates experience problems with local women, future research may want to examine how they position themselves vis-à-vis other women and how these positioning strategies differ from the ones they use vis-à-vis male actors. In a similar vein, future research may want to compare female expatriates' interpreting and positioning strategies when interacting with local men versus men from headquarters. As discussed before, the identity discourse of culture may not be a relevant option in the latter case, forcing female expatriates to rely on other available identity discourses.

Fourth, the critical incidents that we analyzed refer to experienced difficulties within 'traditional' expatriate assignments. As other forms of international contactssuch as short-term international assignment, global teams or self-initiated foreign experience-become more common (Inkson, Arthur, Pringle, \& Barry, 1997; Suutari \& Brewster, 2000), future research may want to examine how women in these newer types of international assignments deploy their agency.

\section{Implications for practice}

Our perspective also offers insights for re-thinking strategies to develop the potential of female expatriates as human resources. Viewing success as something female expatriates 'do,' rather than as a natural personal characteristic, opens up new options for both women themselves and for International Human Resource (IHR) practitioners.

This study suggests the crucial role of behaviours and tactics through which female expatriates can take an active stance in turning a difficult situation into a more favourable one. Further building on the findings of this study, Table 2 summarizes effective positioning strategies female expatriates might use in specific situations. The selection of appropriate strategies remains, however, contingent upon the way they themselves interpret the interaction.

If interactions are interpreted as gendered, female expatriates should move attention away from gender. They can do so by positioning themselves along hierarchy through relying on their own or others' hierarchical power; or along culture through emphasizing the meaning or value of their own cultural background. If interactions are interpreted as hierarchical, we suggest creating more egalitarian relations. Female expatriates can reduce hierarchical differences through their female skills or through emphasizing the value of each others' cultures. If interactions are interpreted as cultural, female expatriates can use gender positioning to create better relationships and

Table 2

Positioning strategies for female expatriates

\begin{tabular}{|c|c|}
\hline Interpretation of interactions & Possible effective positioning strategies \\
\hline $\begin{array}{l}\text { If you are in a disadvantageous } \\
\text { position because of your gender, ... }\end{array}$ & $\begin{array}{l}\text { Option 1: Hierarchical positioning } \\
\ldots \text { make use of your hierarchical power to challenge unacceptable behaviour and/or } \\
\text { to make each other's roles and responsibilities clear. } \\
\ldots \text { turn to (trusted) people with a higher rank to suppress rumours of incapability. } \\
\text { Option 2: Cultural positioning } \\
\ldots \text { refer to your different cultural background to de-emphasize the negative connotations } \\
\text { of being a woman. } \\
\ldots \text { refer to your different cultural background to stress the qualities associated with your culture. }\end{array}$ \\
\hline $\begin{array}{l}\text { If you are in a disadvantageous } \\
\text { position because of your } \\
\text { hierarchical position, ... }\end{array}$ & $\begin{array}{l}\text { Option 1: Gender positioning } \\
\text {... use your female/soft skills to create non-threatening relations with supervisors } \\
\text { (one-down positioning). } \\
\text {... use your female/soft skills to create trustful relations with people at lower hierarchical levels. } \\
\text { Option 2: Cultural positioning } \\
\text {... learn and respect the other culture(s) to create more egalitarian relations with subordinates. } \\
\text {.. stress that collaboration among different cultures may lead to synergies. }\end{array}$ \\
\hline $\begin{array}{l}\text { If you are in a disadvantageous } \\
\text { position because of your } \\
\text { culture,... }\end{array}$ & $\begin{array}{l}\text { Option 1: Gender positioning } \\
\text {... use your female/soft skills to create trustful relations with locals and/or to overcome } \\
\text { cultural stereotypes. } \\
\text {. . rely on your female, relational skills to maintain a good relationship with locals } \\
\text { even if you impose a different style of doing business. } \\
\text { Option 2: Hierarchical positioning } \\
\quad \ldots \text { use your hierarchical power to challenge unacceptable cultural behaviours. } \\
\text {... turn to people with a higher rank to defend your argument against locals. }\end{array}$ \\
\hline
\end{tabular}


reduce cultural distance. Alternatively, hierarchical positioning can be deployed to make one's argument. Overall, an effective response aims to make differences acceptable either by referring to similarities, by creating good relationships, or by emphasizing the positive aspects of each others' differences. Finally, if responses are constrained because female expatriates experience low status on more than one identity discourse, they need to identify and position themselves along other available identity discourses, such as their professional expertise and experience.

The results of this study also carry implications for IHRM and, in particular, for the selection and training of female expatriates. IHR managers are advised to select female expatriates who can demonstrate their ability to overcome barriers by shifting their positioning strategy to more favourable identity discourses. On its part, to increase female expatriates' chances of success, organizations should make sure that there be as many as possible empowering identity discourses available to them. Sending female expatriates in high positions, with sufficient professional experience and making sure that they receive adequate support from superiors in the local context might be crucial for their success.

Besides careful selection and placement, IHR managers can provide training that helps reframing issues traditionally ascribed to gender in international management. Such training focuses on female expatriates' agency and may consist of different modules: selfassessment exercises, presentation of key concepts, and skill applications (Brislin \& Yoshida, 1994). In a first step, self-assessment exercises are used to increase female expatriates' awareness of one's most dominant interpreting and positioning strategy when confronted with different situations. Through a case study or a questionnaire in which statements describe particular interactions with male actors in the host country, the trainees discuss their responses with each other and, by doing so, they become aware of different possible options and discover their own dominant response mode.

In a next module, key concepts are introduced that assist trainees in developing effective strategies. Following the insights of this study, these concepts focus on gender, hierarchy and culture as three powerladen discourses that constrain but also enable female expatriates' actions. Through introducing not only gender but also hierarchy and culture, the purpose is to change trainees' reference frame and teach them that interactions can be interpreted in multiple ways and that particular discourses are linked to power and identity. Other concepts that are introduced are the two processes of interpreting and positioning through which female expatriates can develop their agency. Here, the aim is to teach them to selectively interpret and strategically position themselves within interactions. Considering our findings, it is crucial for female expatriates to learn to interpret their subordinate position along one specific identity discourse and consequently position themselves in a more favourable way along other available and relevant discourses. Table 2, as developed above, can assist trainees in developing insights into these two processes.

Finally, the module of skill applications serves to practice effective strategies. Through role plays or group discussions, various interpreting scenarios and different positioning strategies can be tried out and discussed. Within this module, it is not only important to learn which discourses to use, but also how to stress them. As our findings indicate, one can position oneself in a favourable way in two ways: either one can stress one's superiority along a particular discourse or one can opt to 'soften' the power relation within that discourse. As Table 2 indicates, the general advice is to make differences acceptable through creating more egalitarian relationships. This type of skill-training can lead to an increased awareness and practice-building of agency, representing a valuable asset for female expatriates' success.

\section{Conclusion}

To conclude on a more reflective note, the female expatriates' strategies for success analyzed and recommended in this paper are individual strategies. This is due to the fact that female expatriates are often the only woman on a specific assignment or, at best, a small minority. While more collective manifestations of female expatriates' agency are not excluded, they are, in these circumstances, highly unlikely. The effects of individual, context-specific 'micro-strategies' on structure are, however, not straightforward. Even in the every-day pursue of their goals, individuals do, through their actions, re-create the structure around them (Willmott, 1987 based on Giddens, 1979, 1984). This means, paradoxically, that female expatriates, in their interactions, at once maintain the structure that penalizes them while also undermine it. Despite the fact that they themselves are successful, their success does not necessarily alter the power relations that make it difficult for women to be international managers.

\section{References}

Acker, J. (1990). Hierarchies, jobs, bodies: A theory of gendered organizations. Gender and Society, 4: 139-158. 
Adler, N. J. (1984a). Expecting international success: Female managers overseas. Columbia Journal of World Business, 19(3): 7985 .

Adler, N. J. (1984b). Women do not want international careers: And other myths about international management. Organizational Dynamics, 13(2): 66-80.

Adler, N. J. (1984c). Women in international management: Where are they? California Management Review, 26(4): 78-89.

Adler, N. J. (1987). Pacific basin managers: A Gaijin, not a woman. Human Resource Management, 26: 169-192.

Adler, N. J. (1994). Competitive frontiers: Women managing across borders. Journal of Management Development, 13(2): 24-41.

Adler, N. J. (2002). Global managers: No longer men alone. The International Journal of Human Resource Management, 13: 743760.

Adler, N. J., Brody, L. W., \& Osland, J. S. (2000). The women's global leadership forum: Enhancing one company's global leadership capability. Human Resource Management, 39: 209-225.

Alvesson, M., \& Billing, Y. D. (1997). Understanding gender and organizations. London: Sage.

American Institute for Research (AIR). (1998, April). The Critical Incident Technique. AIR Web Page. Available at WWW URL http://www.air.org/about/critical.html.

Anthias, F., \& Yuval-Davis, N. (1992). Connecting race and gender. In F. Anthias, \& N. Yuval-Davis (Eds.), Racialized boundaries, race, nation, gender, colour and class and the anti-racist struggle (pp. 96-131). London: Routledge.

Bell, E. L., \& Nkomo, S. M. (1992). Re-visioning women manager's lives. In A. J. Mills, \& P. Tancred (Eds.), Gendering organizational analysis (pp. 235-247). Newbury Park: Sage.

Biernacki, P., \& Waldorf, D. (1981). Snowball sampling: Problems and techniques of chain referral sampling. Sociological Methods and Research, 10(2): 141-163.

Black, J. S. (1990). Locus of control, social support, stress and adjustment in international transfers. Asia Pacific Journal of Management, 7(1): 1-29.

Black, J. S., \& Gregersen, H. B. (1991). When Yankee comes home: Factors related to expatriate and spouse repatriation adjustment. Journal of International Business Studies, 22: 671-695.

Brislin, R. W., \& Yoshida, T. (1994). The content of cross-cultural training: An introduction. In R. W. Brislin, \& T. Yoshida (Eds.), Improving intercultural interactions. Modules for cross-cultural training programs (pp. 1-14). Thousand Oaks: Sage Publications.

Caligiuri, P. M. (1997). Assessing expatriate success: Beyond just being there. In Z. Aycan (Ed.), Expatriate management: Theory and practice (pp. 117-140). Greenwich, CT: JAI Press.

Caligiuri, P. M., \& Cascio, W. (1998). Can we send her there? Maximizing the success of western women on global assignments. Journal of World Business, 33: 394-417.

Caligiuri, P. M., \& Tung, R. L. (1999). Comparing the success of male and female expatriates from a US-based multinational company. The International Journal of Human Resource Management, 10: 763-782.

Church, A. (1982). Sojourner adjustment. Psychological Bulletin, 9: 540-572.

Davies, B., \& Harré, R. (1990). Positioning: The discursive production of selves. Journal of the Theory of Social Behavior, 1: 43-63.

Denzin, N. K. (1978). The research act: A theoretical introduction to sociological methods (2nd ed.). New York: McGraw-Hill.

Edström, A., \& Galbraith, J. R. (1977). Transfer of managers as a coordination and control strategy in multinational organizations. Administrative Science Quarterly, 22: 248-264.
Eisenhardt, K. M. (1989). Building theories from case study research. Academy of Management Review, 14: 488-511.

Fagenson, E. A. (1990). At the heart of women in management research: Theoretical and methodological approaches and their biases. Journal of Business Ethics, 9: 274-367.

Fischlmayr, I. C. (2002). Female self-perception as barrier to international careers? The International Journal of Human Resource Management, 13: 773-783.

Flanagan, J. C. (1954). The critical incident technique. Psychological Bulletin, 51: 327-358.

Gergen, K. J., \& Davis, K. E. (1985). The social construction of the person. New York: Springer-Verlag.

Gherardi, S. (1995). Gender, symbolism and organizational cultures. London: Sage.

Gherardi, S., \& Poggio, B. (2001). Creating and recreating gender order in organizations. Journal of World Business, 36: 245-259.

Giddens, A. (1979). Central problems in social theory. London: MacMillan.

Giddens, A. (1982). Profiles and critiques in social theory. London: MacMillan.

Giddens, A. (1984). The constitution of society. Cambridge: Polity Press.

Glaser, B., \& Strauss, A. (1967). The discovery of grounded theory. New York: De Gruyter.

Goffman, E. (1959). The presentation of self in everyday life. New York: Anchor Books Doubleday.

Goodman, L. (1961). Snowball sampling. Annals of Mathematical Statistics, 32(1): 148-170.

Harris, H. (1995). Organizational influences on women's career opportunities in international management. Women in Management Review, 10(3): 26-31.

Inkson, K., Arthur, M. B., Pringle, J., \& Barry, S. (1997). Expatriate assignment versus overseas experience: Contrasting models of international human resource development. Journal of World Business, 32: 351-369.

Izraeli, D. N., \& Adler, N. J. (1994). Competitive frontiers: Women managers in a global economy. In N. J. Adler, \& D. N. Izraeli (Eds.), Competitive frontiers: Women managers in a global economy (pp. 3-21). Cambridge, MA: Blackwell.

Janssens, M. (1994). Evaluating international managers' performance: Parent company standards as control mechanism. The International Journal of Human Resource Management, 5: 853-873.

Kalton, G., \& Anderson, D. W. (1986). Sampling rare populations. Journal of the Royal Statistical Society, 149: 65-82.

Linehan, M., \& Walsh, J. S. (1999). Recruiting and developing female managers for international assignments. Journal of Management Development, 18: 521-530.

Lowe, K. B., Downes, M., \& Kroeck, K. G. (1999). The impact of gender and location on the willingness to accept overseas assignments. The International Journal of Human Resource Management, 10: 223-234.

Mayrhofer, W., \& Scullion, H. (2002). Female expatriates in international business: Empirical evidence from the German clothing industry. The International Journal of Human Resource Management, 13: 815-836.

McCabe, D. (2000). Factory innovations and management machinations: The productive and repressive relations of power. Journal of Management Studies, 37: 931-953.

McNay, L. (2000). Gender and agency: Reconfiguring the subject in feminist and social theory. Cambridge: Polity.

Napier, N., \& Taylor, S. (2002). Experiences of women professionals abroad: Comparisons across Japan, China and Turkey. The 
International Journal of Human Resource Management, 13: $837-851$

O’Donnell, M. H. (2003). Radically reconstituting the subject: Social theory and human nature. Sociology, 37: 753-770.

Skeggs, B. (1997). Formations of class and gender. London: Sage.

Stroh, L. K., Varma, A., \& Valy-Durbin, S. J. (2000). Why are women left at home: Are they unwilling to go on international assignment? Journal of World Business, 35: 241-256.

Suutari, V., \& Brewster, C. (2000). Making their own way: International experience through self-initiated foreign assignments. Journal of World Business, 35: 417-436.

Taylor, S., \& Napier, N. (1996). Working in Japan: Lessons from women expatriates. Sloan Management Review, 37(3): 76-84.

Tung, R. L. (1981). Selection and training of personnel for overseas assignments. Columbia Journal of World Business, 16(1): 68-78.
Van Maanen, J. (1979). On the understanding of interpersonal relations. In W. Bennis, J. Van Maanen, E. Schein, \& F. Stelle (Eds.), Essays in interpersonal dynamics (pp. 13-42). Homewood, IL: The Dorsey Press.

West, C., \& Zimmerman, D. (1991). Doing Gender. In J. Lorber, \& S. A. Farrell (Eds.), The social construction of gender (pp. 13-37). Newbury Park: Sage.

Westwood, R. I., \& Leung, S. M. (1994). The female expatriate manager experience. Coping with gender and culture. International Studies of Management and Organization, 24(3): 6485.

Willmott, H. (1987). Studying managerial work: A critique and a proposal. Journal of Management Studies, 24: 149-270.

Yin, R. K. (1989). Case study research: Design and methods. Newbury Park, CA: Sage. 